Original Research Paper

\title{
Isolation and Characterization of Potassium-Solubilizing Bacteria from Two Different Rhizospheres and a Cow Manure in IPB University
}

\author{
Dori Kusuma Jaya ${ }^{*}$, Sari Yulia Kartika Hasibuan², Deseriana Bria ${ }^{3}$ \\ ${ }^{1}$ Program Studi Biologi, Fakultas Sains dan Teknologi, Universitas Qamarul Huda Badaruddin, Bagu \\ Lombok Tengah, Indonesia; \\ ${ }^{2}$ Program Studi Sains Perkopian, Universitas Pat Petulai, Bengkulu, Indonesia; \\ ${ }^{3}$ Program Studi Agroteknologi, Fakultas Pertanian, Universitas Timor, Indonesia
}

\author{
Article History \\ Received : March, 13 ${ }^{\text {th }}, 2021$ \\ Revised : March, 31 $1^{\text {th }}, 2021$ \\ Accepted : April 21 $1^{\text {th }}, 2021$ \\ Published : May $03^{\text {th }}, 2021$ \\ *Corresponding Author: \\ Dori Kusuma Jaya, \\ Program Studi Biologi, \\ Fakultas Sains dan Teknologi, \\ Universitas Qamarul Huda \\ Badaruddin, Bagu Lombok \\ Tengah, Indonesia; \\ Email: dorijaya93@gmail.com
}

\begin{abstract}
Applying PGPB (Plant Growth-Promoting Bacteria) as bioinoculant under the excessive and continuous use of chemical fertilizer, pesticide, and herbicide need to be highlighted nowadays. One of the most beneficial PGPB is potassium-solubilizing rhizobacteria. Potassium is one of the elements that plant absorbs in a large amounts along with nitrogen. Soil in various regions of Indonesia have low potassium solubility. Therefore, finding the best novel isolates contributing to potassium solubilization need to be carried out continually. The aim of this study is to find potassium-solubilizing bacteria from two different rhizospheres (banana and chili plant) in Leuwikopo Experimental Garden and a cow manure in Cattle Pen, IPB University. To obtain the potassium-solubilizing isolates, we observed and characterized the best growing isolates and measured the solubilizing zone on Alexandrov agar medium. Three out of 10 isolates were selected and tested their pathogenicity on tobacco leave. Solubilization index of three isolates from the highest to the lowest were MPK P (3.07), MPK KT (3.03), and MPK C (2.63), respectively. Necrotic on tobacco leave after isolates treatment showed negative result which means that the three isolates were not pathogenic to plant host. The isolates are recommended to be used as bioinoculant both in greenhouse and field plants which lack of potassium availability in soil.
\end{abstract}

Keywords: Bioinoculant; feldspar; plant rhizosphere; potassium solubilization

\section{Pendahuluan}

Penggunaan PGPB (Plant GrowthPromoting Bacteria) atau secara khusus yang berasosiasi dengan akar tanaman juga dikenal sebagai PGPR (Plant Growth-Promoting Rhizobacteria) sebagai bioinokulan pemacu pertumbuhan tanaman di tengah penggunaan pupuk kimia, pestisida, dan herbisida yang terus menerus dan berlebihan saat ini sangat perlu diperhatikan. Kerusakan ekosistem tanah akibat penggunaan pupuk kimia yang terus menerus dan berlebihan salah satunya dapat diperbaiki dengan menggunakan PGPR. PGPR merupakan sekelompok bakteri bermanfaat yang hidup di daerah rizosfer tanaman (lapisan tanah 1-2 mm di sekitar akar) atau bersimbiosis dengan akar tanaman. Kebermanfaatan PGPR ini dapat dirasakan oleh tanaman baik secara langsung maupun tidak langsung. Secara langsung kelompok bakteri ini mampu menyediakan dan memobilisasi penyerapan berbagai unsur hara tanah serta mensintesis berbagai fitohormon. Sedangkan secara tidak langsung bakteri ini mampu menekan aktivitas patogen melalui senyawa atau metabolit sekunder yang dihasilkannya (Kloepper, 1993; Glick, 1995). Kelompok bakteri yang termasuk PGPR yang telah banyak dilaporkan adalah Arthrobacter, Variovorax, Azospirillum, Alcaligenes, Bradyrhizobium, Burkholderia, Azotobacter, Streptomyces, Bacillus, Pseudomonas dan 
sebagainya (Ahmad et al., 2008; Tariq et al., 2014; Gupta et al., 2016).

Salah satu PGPR yang paling penting adalah mikroba pelarut kalium. Kalium merupakan salah satu makronutrien yang dapat mempengaruhi pertumbuhan tanaman, kualitas dan perkembangan buah, berperan penting dalam sintesis sel, enzim, protein, karbohidrat, selulosa, dan vitamin. Selain itu, kalium tidak hanya berperan dalam transportasi penyerapan nutrisi, tetapi juga berperan dalam resistensi cekaman biotik dan abiotik yang mana berujung pada peningkatan kualitas tanaman pangan dan resistensi tanaman terhadap penyakit (Pettigrew, 2008; Maqsood et al., 2013). Kalium merupakan salah satu unsur yang diserap tanaman dalam jumlah besar dibandingkan dengan unsur-unsur lainnya bersama dengan nitrogen. Oleh karena itu, ketersediaan kalium di dalam tanah sangat penting bagi tanaman. Sayangnya, lebih dari 90 hingga 98\% kalium tanah masih terikat dengan mineral yang mana tidak dapat diserap oleh tanaman. Tanah di berbagai daerah di Indonesia memiliki kelarutan kalium yang rendah karena masih terikat dengan mineral seperti feldspar dan mika (Pratama et al., 2016). Berbagai penelitian melaporkan bahwa mikroba tanah dapat melarutkan mineral silikat seperti feldspar dan mika kemudian mentransformasikan kailum yang tak tersedia menjadi kalium tersedia sehingga dapat diserap oleh akar tanaman (Zhang \& Kong, 2014). Mekanisme PGPR dalam melarutkan kailum tak tersedia adalah dengan cara memproduksi asam organik seperti asam oksalat, asam formiat, asam sitrat, dan asam malat. Asam-sama organik ini dapat mempercepat kelarutan ion kalium dari mineral tanah (Sheng, 2005).

Pencarian bioinokulan terbaru yang dapat melarutkan kalium lebih efektif masih terus dilakukan di berbagai penelitian baik di Indonesia maupun di dunia. Oleh karena itu, penelitian ini bertujuan untuk mengisolasi dan mengkarakterisasi bakteri pelarut kalium terbaru dari rizosfer berbagai tanaman yang ada di kebun percobaan Leuwikopo dan kotoran sapi dari kandang peternakan kampus IPB Bogor dan mengevaluasi keefektifannya dalam melarutkan senyawa kalium tak tersedia pada medium Alexandrov agar.

\section{Bahan dan Metode}

\section{Tempat penelitian dan pengambilan sampel}

Penelitian ini dilakukan di Laboratorium Bioteknologi Tanah dan Lingkungan, Departemen Ilmu Tanah dan Sumberdaya Lahan, Fakultas Pertanian, Pascasarjana Institut Pertanian Bogor mulai September hingga Desember 2019. Sampel tanah rizosfer berasal dari tanaman cabai dan pisang yang ada di kebun percobaan Leuwikopo serta kotoran ternak sapi dari kandang peternakan kampus IPB Bogor. Sampel tanah diambil dengan menggunakan soil sampler dengan kedalaman $20 \mathrm{~cm}$ kemudian dimasukkan ke dalam plastik dan segera disimpan di freezer di laboratorium pada suhu $4^{\circ} \mathrm{C}$.

\section{Isolasi dan karakterisasi isolat}

Sebanyak 10 gram sampel tanah dilarutkan ke dalam $90 \mathrm{ml}$ larum garam fisiologis $0,85 \%$ kemudian dihomogenkan menggunakan shaker. Setelah itu, sebanyak $1 \mathrm{ml}$ suspensi dari masing-masing sampel dimasukkan ke dalam 9 $\mathrm{ml}$ larutan garam fisiologis kemudian dilakukan proses pengenceran bertingkat hingga pengenceran $10^{-6}$ dan dihomogenkan selama beberapa saat menggunakan vortex. Sebanyak $0,1 \mathrm{ml}$ suspensi pada pengenceran $10^{-6}$ diambil kemudian diinokulasikan ke media Alexandrov agar. Medium yang telah diinokulasi kemudian diinkubasi selama 2-3 hari pada suhu $33-37^{\circ} \mathrm{C}$ dan diamati pertumbuhannya. Bakteri pelarut kalium ditandai dengan terbentuknya zona bening disekitar koloni bakteri yang tumbuh. Berbagai macam isolat yang tumbuh lalu dimurnikan pada media Alexandrov yang baru untuk dikarakterisasi lebih lanjut (Prajapati \& Modi, 2012).

Isolat yang membentuk zona bening pada media Alexandrov agar dilakukan pengamatan terhadap karakter morfologi koloni dan juga fisiologisnya. Karakter morfologi koloni yang diamati meliputi bentuk, permukaan, tekstur, warna, dan tepian koloni. Sedangkan karakter fisiologis yang diamati meliputi $\mathrm{pH}$, motilitas, kebutuhan oksigen, katalase, dan fermentasi glukosa dan sukrosa (Fatharani \& Rahayu, 2018).

\section{Pengukuran indeks pelarutan kalium}

Isolat bakteri dengan indeks pelarutan kalium terbaik pada media Alexandrov agar dipilih untuk dijadikan sebagai kandidat 
bioinokulan pelarut kalium setelah melewati tahap uji patogenitas pada daun tembakau. Medium Alexandrov mengandung glukosa 5,0 g, agar 20, $\mathrm{MgSO}_{4} .7 \mathrm{H}_{2} \mathrm{O} 0,5 \mathrm{~g}, \mathrm{CaCO}_{3} 0,1 \mathrm{~g}, \mathrm{FeCl}_{3}$ $0,006 \mathrm{~g}, \mathrm{Ca}_{3} \mathrm{PO}_{4} 2,0 \mathrm{~g}$, dan Feldspar $3 \mathrm{~g}$ yang dilarutkan ke dalam 1 L akuades (Prajapati \& Modi, 2012). Indeks pelarutan kalium diukur dengan cara menghitung rasio antara zona bening yang terbentuk dengan diameter koloni isolat.

\section{Uji patogenitas pada daun tembakau}

Uji patogenitas isolat pelarut kalium pada daun tembakau menggunakan metode Marques et al. (2016) dengan modifikasi konsentrasi isolat yang digunakan adalah $10^{6} \mathrm{cfu}$ $\mathrm{ml}^{-1}$ dan diinkubasi selama 48 jam. Uji ini bertujuan untuk mengetahui apakah isolat terpilih dapat menyebabkan nekrosis pada daun tembakau atau tidak yang ditandai dengan berubahnya daun tembakau menjadi berwarna kuning dan coklat seteleh 48 jam inkubasi. Jika daun tembakau tidak menunjukkan gejala nekrosis maka isolat bakteri terpilih dapat dijadikan sebagai kandidat bioinokulan. Sebanyak $10^{6} \mathrm{cfu} \mathrm{ml}^{-1}$ isolat terpilih yang telah dikultur pada media NB (Nutrient Broth) disuntikkan menggunakan jarum spuit ke bagian mesofil daun tembakau berumur 3 bulan kemudian diinkubasi pada suhu ruang selama 48 hari.

\section{Hasil dan Pembahasan}

\section{Indeks pelarutan kalium}

Tiga dari 10 isolat dengan pertumbuhan terbaik mampu melarutkan kalium pada medium Alexandrov agar. Ketiga isolat tersebut masingmasing berasal dari rizosfer tanaman pisang dan cabai serta kotoran ternak sapi. Ketiga isolat tersebut menunjukkan zona bening di sekitar koloni yang mengindikasikan bahwa isolat-isolat tersebut mampu melarutkan kalium tak tersedia dari feldspar yang ada pada media Alexandrov agar (Gambar 1). Tabel 1 menunjukkan bahwa indeks pelarutan kalium terbaik dimiliki oleh isolat yang berasal dari rizosfer tanaman pisang (MPK P) yaitu sebesar 3,07 dan diikuti oleh isolat asal kotoran ternak (MPK KT) yaitu 3,03, dan yang terendah adalah isolat asal rizosfer tanaman cabai (MPK C) yaitu 2,63.

Tabel 1. Indeks pelarutan kalium isolat bakteri pada media Alexandrov agar

\begin{tabular}{lccc} 
Isolat & Diameter zona bening $(\mathbf{c m})$ & Diameter koloni $(\mathbf{c m})$ & $\begin{array}{c}\text { Indeks pelarutan kalium } \\
\text { (rasio zona bening/koloni) }\end{array}$ \\
\hline MPK C & 1,00 & 0,38 & 2,63 \\
MPK P & 1,23 & 0,40 & 3,07 \\
MPK KT & 1,91 & 0,63 & 3,03 \\
\hline
\end{tabular}

Keterangan: MPK C: Mikroba pelarut kalium asal rizosfer tanaman cabai; MPK P: Mikroba pelarut kalium asal rizosfer tanaman pisang; MPK KT: Mikroba pelarut kalium asal kotoran ternak.
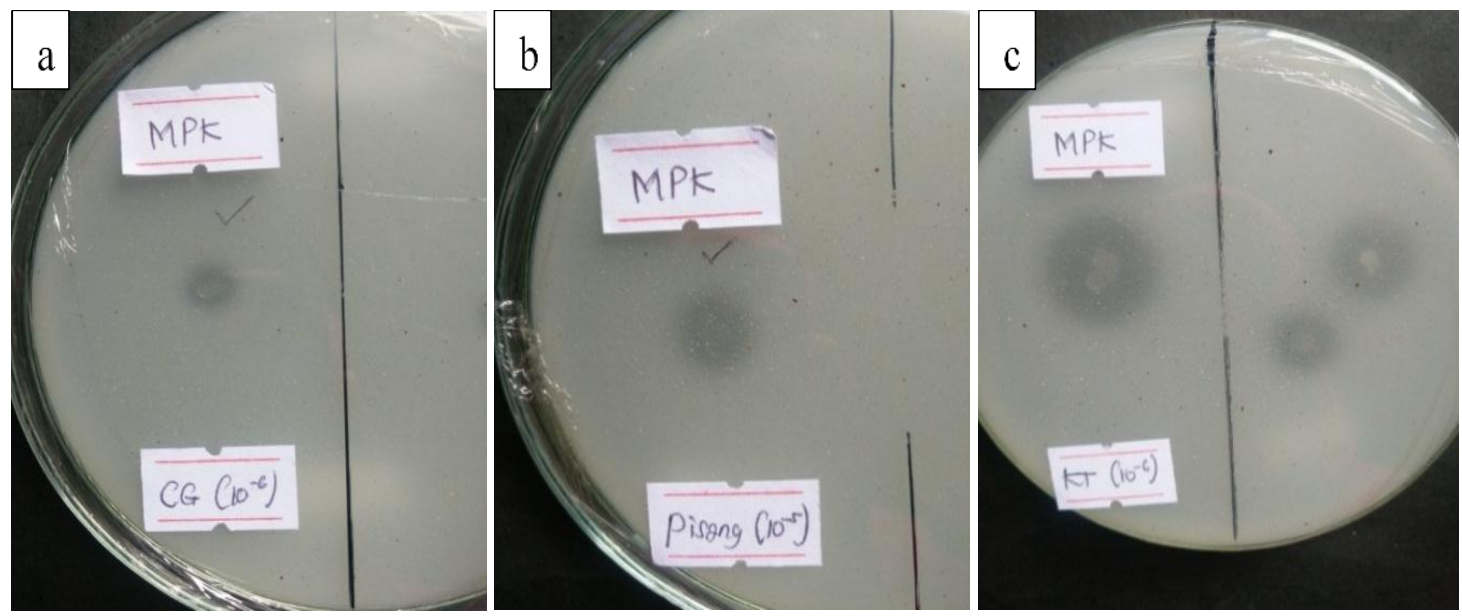

Gambar 1. Zona pelarutan kalium isolat bakteri pada media Alexandrov agar. a. Isolat MPK C; b. 
Isolat MPK P; c. Isolat MPK KT.

\section{Karakter morfologi koloni isolat}

Karakter morfologi koloni isolat bakteri pelarut kalium ditunjukkan pada Tabel 2. Ketiga isolat bakteri memperlihatkan karakter morfologi yang mirip antara isolat MPK C dan MPK P kecuali pada tepian koloni yang bersifat rata dan irreguler secara berturut-turut. Sementara pada isolat MPK KT menunjukkan karakter morfologi yang lebih berbeda dibandingkan kedua isolat yang lain.

Tabel 2. Karakter morfologi koloni isolat bakteri pelarut kalium pada media Alexandrov agar

\begin{tabular}{llllll}
\hline \multicolumn{1}{c}{ Isolat } & Bentuk & Permukaan & \multicolumn{1}{c}{ Tekstur } & \multicolumn{1}{c}{ Warna } & Tepian \\
\hline MPK C & Lonjong & Cembung & Mengkilap & Putih bening & Rata \\
MPK P & Lonjong & Cembung & Mengkilap & Putih bening & Irreguler \\
MPK KT & Bulat & Rata & Mengkilap & Kuning pucat & Irreguler \\
\hline
\end{tabular}

Keterangan: MPK C: Mikroba pelarut kalium asal rizosfer tanaman cabai; MPK P: Mikroba pelarut kalium asal rizosfer tanaman pisang; MPK KT: Mikroba pelarut kalium asal kotoran ternak.

\section{Karakter fisiologis isolat}

Tabel 3 memperlihatkan karakter fisiologis isolat yang berbeda-beda satu sama lain kecuali antara isolat MPK P dan MPK KT pada karakter motilitas. Ketiga isolat mampu tumbuh paling baik pada $\mathrm{pH}$ 7. Isolat MPK C memiliki kemampuan motilitas yang mengindikasikan bahwa isolat bakteri tersebut memiliki flagela sebagai alat geraknya. Sedangkan dalam hal kebutuhan oksigen semua isolat bersifat anaerob yang berarti bahwa ketiga isolat tidak mampu menggunakan oksigen bebas. Selain itu, ketiga isolat tidak mampu mengoksidasi hidrogen peroksida dan memfermentasi gula.

Tabel 3. Karakter fisiologis isolat bakteri pelarut kalium pada media NB (Nutrient Broth)

\begin{tabular}{cccc}
\hline Karakter & MPK C & MPK P & MPK KT \\
\hline OD pada pH 3 & 0,037 & 0,038 & 0,051 \\
OD pada pH 5 & 0,270 & 0,374 & 0,253 \\
OD pada pH 6 & 0,340 & 0,379 & 0,345 \\
OD pada pH 7 & 0,432 & 0,636 & 0,397 \\
OD pada pH 9 & 0,034 & 0,077 & 0,034 \\
Motilitas & - & + & + \\
Oksigen & Anaerob & Anaerob & Anaerob \\
Katalase & - & - & - \\
Fermentasi glukosa & - & - & - \\
Fermentasi sukrosa & - & - & - \\
\hline
\end{tabular}

Keterangan: MPK C: Mikroba pelarut kalium asal rizosfer tanaman cabai; MPK P: Mikroba pelarut kalium asal rizosfer tanaman pisang; MPK KT: Mikroba pelarut kalium asal kotoran ternak

\section{Uji patogenitas bakteri pelarut kalium}

Uji patogenitas harus dilakukan bagi isolat bakteri yang menjadi kandidat bioinokulan pelarut kalium. Uji ini bertujuan untuk mengetahui apakah isolat yang diperoleh dari sampel merupakan isolat patogen atau tidak. Isolat yang bersifat patogen baik pada tanaman maupun pada manusia tidak dapat dijadikan sebagai bioinokulan. Tabel 4 memperlihatkan bahwa daun tembakau tidak menunjukkan adanya gejala nekrosis setelah diinokulasi dengan isolat pelarut kalium setelah 48 jam inkubasi. Hal ini membuktikan bahwa semua isolat tidak bersifat patogen.

Tabel 4. Uji patogenitas isolat bakteri pelarut kalium pada daun tembakau

\begin{tabular}{cc}
\hline Isolat & Hasil uji \\
\hline MPK C & Tidak nekrosis
\end{tabular}




$\begin{array}{cc}\text { MPK P } & \text { Tidak nekrosis } \\ \text { MPK KT } & \text { Tidak nekrosis }\end{array}$

Keterangan: MPK C: Mikroba pelarut kalium asal rizosfer tanaman cabai; MPK P: Mikroba pelarut kalium asal rizosfer tanaman pisang; MPK KT: Mikroba pelarut kalium asal kotoran ternak.

Kemampuan isolat bakteri perakaran asal beberapa rizosfer tanaman dan kotoran sapi pada penelitian ini dipelajari pada media Alexandrov agar yang mengandung feldspar sebagai satu-satunya sumber kalium tak tersedia pada media. Indeks pelarutan kalium digunakan untuk mengukur zona pelarutan kalium. Tiga isolat bakteri terbaik dipilih sebagai kandidat isolat pelarut kalium yang mana indeks pelarutan tertinggi ke terendah berturut-turut dimiliki oleh isolat MPK P (3,07), MPK KT (3,03), dan MPK C $(2,63)$ (Tabel 1 dan Gambar 1). Pembebasan kailum dari mineral feldspar pada media umumnya diawali dengan produksi asam-asam organik selama pembelahan sel bakteri. Perbedaan indeks kelarutan kalium diduga disebabkan oleh produksi dan konsentrasi asam organik yang berbeda-beda yang dilepaskan ke media untuk melarutkan kalium (Meena et al., 2015; Fatharani \& Rahayu, 2018). Isolat asal rizosfer pisang (MPK P) mampu membebaskan ion kalium paling baik dari feldspar (Tabel 2). Karakter morfologi isolat mirip seperti yang dilaporkan oleh Fatharani \& Rahayu (2018) dalam beberapa hal dan berbeda pada karakter fisiologis. Selain itu, syarat yang harus dipenuhi oleh isolat kandidat bioinokulan adalah tidak bersifat patogen terhadap tanaman inang ataupun manusia (Tabel 4). Berbagai penelitian juga melaporkan bahwa isolat bakteri pelarut kalium dapat ditemukan dari berbagai rizosfer tanaman, misalnya rizosfer tanaman jagung (Zea mays), tanaman pisang (Musa paradisiaca), tanaman tebu (Saccharum officinarum), tanaman kentang (Solanum tuberosum), dan tembakau (Nicotiana tabacum). Isolat bakteri pelarut kalium asal semua rizosfer tersebut menunjukkan indeks pelarutan kalium antara 1,29 hingga 2,34 dengan indeks pelarutan tertinggi dimiliki oleh isolat asal rizosfer tanaman jagung (Zea mays) yaitu 2,34 (Meena et al., 2015). Hasil ini masih lebih rendah dibandingkan dengan hasil penelitian kami bahwa indeks pelarutan kalium terbaik dimiliki oleh isolat asal rizosfer tanaman pisang (MPK P) yaitu 3,07 yang disusul oleh isolat asal kotoran ternak (MPK KT) yaitu 3,03 (Tabel 1). Meskipun demikian ada isolat yang lebih baik dalam melarutkan kalium yaitu berasal dari rizosfer tanaman padi (Oryza sativa L.) dengan indeks pelarutan kalium tertinggi 5,25 (Fatharani \& Rahayu, 2018). Perbedaan hasil ini selain disebabkan oleh perbedaan jenis maupun konsentrasi asam organik yang dihasilkan oleh isolat-isolat juga diduga karena peran dari eksudat akar yang disekresikan oleh berbagai tanaman yang berbeda-beda (Fatharani \& Rahayu, 2018; Singh, 2018). Hal ini mungkin dapat pula terjadi pada perbedaan komposisi antara media Alexandrov agar dengan eksudat akar secara alami.

Kalium sebagai salah satu unsur utama bagi perumbuhan tanaman berperan dalam mengaktivasi paling tidak 60 enzim berbeda yang terlibat dalam pertumbuhan dan produktivitas tanaman. Berbagai anion organik dan senyawa anorganik lainnya juga dapat dinetralkan oleh adanya kalium di dalam jaringan tanaman. Oleh karena itu, tanaman cabai dan pisang sebagai asal isolat bakteri pelarut kalium penelitian ini tidak perlu khawatir akan kekurangan kalium tersedia. Plant growthpromoting rhizobacteria (PGPR) yang ditemukan di rizosfer berbagai tanaman tidak hanya berperan dalam melarutkan kalium tanah tetapi juga menonjolkan efek kebermanfaatan lainnya dalam penyerapan nutrisi dan mobilisasi unsur hara melalui mekanisme yang beragam seperti fiksasi nitrogen, produksi fitohormon, siderofor, dan mobilisasi makro dan mikronutrien seperti, fosfat, zink, tembaga, dan zat besi (Teotia et al., 2016). Oleh karena itu, penggunaan PGPR kususnya bagi isolat pelarut kalium sebagai bioinokulan dalam bidang pertanian sangat perlu dilakukan guna memfasilitasi ketersediaan unsur kalium bagi tanaman pangan sehingga dapat berujung pada meningkatnya produktivitas tanaman.

Isolat bakteri pelarut kalium penelitian ini dapat dijadikan sebagai bioinokulan khususnya sebagai pupuk hayati karena sudah melewati uji patogenitas. Namun demikian, kekurangan dalam identifikasi spesies bakteri menjadi kendala tersendiri dalam memastikan spesies bakteri yang diperoleh. Hal ini karena terkendala dalam bahan habis pakai di laboratorium seperti reagen untuk proses ekstraksi DNA yang bertujuan untuk 
mengidentifikasi spesies bakteri secara molekuler. Oleh karena itu, perlu perencanaan komperehensif dalam melakukan penelitian agar sampai pada proses identifikasi spesies baik secara biokimia maupun molekuler.

Saat ini penggunakan bakteri pelarut kalium sebagai bioinokulan pupuk hayati telah banyak diterapkan dalam bidang pertanian dan konservasi lingkungan bahkan mendapat perhatian dalam skala komersial (Meena et al., 2014; Teotia et al., 2016). Prospek yang sedang berkembang saat ini dan masa depan bagi PGPR pelarut kalium adalah kajian pada tingkat molekuler yaitu potensi kloning gen yang bertanggung jawab terhadap pelarutan kalium ke dalam bakteri lain yang memiliki kemampuan reproduksi dan viabilitas yang tinggi di rizosfer serta kemampuan memfiksasi nitrogen bebas, pelarutan fosfat, dan produksi fitohormon. Selain itu, efisiensi pelarutan kalium dapat ditingkatkan dengan cara mengembangkan dan memperbaiki teknik kultur isolat guna menunjang viabilitasnya di rizosfer (Teotia et al., 2016).

\section{Kesimpulan}

Tiga dari 10 isolat bakteri pada penelitian ini mampu melarutkan kalium terikat mineral feldspar yang terdapat pada media Alexandrov agar dengan indeks pelarutan tertinggi ke terendah berturut-turut MPK P, MPK KT, dan MPK C. Ketiga isolat tersebut dapat dijadikan sebagai bioinokulan karena telah melewati uji patogenitas yang harus dipenuhi. Penerapan isolat bakteri pelarut kalium sebagai bioinokulan pupuk hayati yang diperoleh pada penelitian ini perlu dilakukan uji pada tanaman. Penelitian-penelitian selanjutnya perlu dilakukan perencanaan penelitian yang komprehensif agar dapat dilakukan identifikasi spesies bakteri secara molekuler untuk keperluan komersial di masa mendatang.

\section{Ucapan terima kasih}

Terima kasih kami ucapkan kepada ketua Program Studi Bioteknologi Tanah dan Lingkungan Pascasarjana IPB beserta staf laboran laboratorium yang telah memfasilitasi dan membantu jalannya penelitian ini serta dukungan pendanaan penelitian yang diberikan. Terima kasih pula kami ucapkan kepada rekan- rekan pada Program Studi Biologi UNIQHBA atas kerjasama yang baik.

\section{Referensi}

Ahmad, F., Ahmad, I., \& Khan, M. S. (2008). Screening of free-living rhizospheric bacteria for their multiple plant growth promoting activities. Microbiological Research, 163, 173-181. DOI: 10.1016/j.micres.2006.04.001

Fatharani, R., \& Rahayu, Y. S. (2018). Isolation and Characterization of PotassiumSolubilizing Bacteria from Paddy Rhizosphere (Oryza sativa L.). Journal of Physics: Conference Series, 1108(1). DOI: 10.1088/1742-6596/1108/1/012105

Glick, B. R. (1995). The enhancement of plant growth by free-living bacteria. Canadian Journal of Microbiology, 41(2), 109-117. DOI: $10.1139 / \mathrm{m} 95-015$

Gupta, A., Gupta, R., \& Singh, R. L. (2016). Microbes and Environment. In Principles and Applications of Environmental Biotechnology for a Sustainable Future, Applied Environmental Science and Engineering for a Sustainable Future (R.L. Singh, pp. 43-83). DOI: 10.1007/978-981-10-1866-4_3

Kloepper, J.W. (1993). Plant growth promoting rhizobacteria as biological control agents. p. 255-274. In F.B. Meeting, Jr. ( Ed .). Soil Microbial Ecology, Applications in Agricultural and Environmental Management. Marcel Dekker, Inc. New York. Retrieved from https://www.cabdirect.org/cabdirect/abstr act $/ 19932338435$

Maqsood, M., Shehzad, M. A., Wahid, A., \& Butt, A. A. (2013). Improving Drought Tolerance in Maize (Zea mays) with Potassium Application in Furrow Irrigation Systems. International Journal of Agriculture and Biology, 15, 11931198. Retrieved from http://www.fspublishers.org/published_pa pers/95461_..pdf 
Marques, E., Borges, R. C., \& Uesugi Carlos H. (2016). Comunicação científica / Scientific communication. Horticultura Brasileira, 34, 244-248. DOI: $10.1590 / \mathrm{S} 0102-053620160000200015$

Meena, V. S., Maurya, B. R., \& Verma, J. P. (2014). Does a rhizospheric microorganism enhance $\mathrm{K}+$ availability in agricultural soils? Microbiological Research, 169(5-6), 337-347. DOI: 10.1016/j.micres.2013.09.003

Meena, V. S., Maurya, B. R., Verma, J. P., Aeron, A., Kumar, A., Kim, K., \& Bajpai, V. K. (2015). Potassium solubilizing rhizobacteria (KSR): Isolation, identification, and K-release dynamics from waste mica. Ecological Engineering, 81(August), $\quad 340-347 . \quad$ DOI: 10.1016/j.ecoleng.2015.04.065

Pettigrew, W. T. (2008). Potassium influences on yield and quality production for maize, wheat, soybean and cotton. Physiologia Plantarum, 133, 670-681. DOI: 10.1111/j.1399-3054.2008.01073.x

Prajapati, K. B., \& Modi, H. A. (2012). Isolation and characterization of potassium solubilizing bacteria from ceramic industry soil. CIBTech Journal of Microbiology, 1(2-3), 8-14. Retrieved from

https://www.researchgate.net/publication/ 284589616_Isolation_and_characterizatio n_of_potassium_solubilizing_bacteria_fr om_ceramic_industry_soil

Pratama, D., Anas, I., \& Suwarno. (2016). Ability of Potassium-Solubilissing Microbes to Solubilise Feldspar and Their Effects on Sorghum Growth. Malaysian Journal of Soil Science, 20, 163-175. Retrieved from http://www.msss.com.my/mjss/Full Text/vol20/11-pratama.pdf

Sheng, X. F. (2005). Growth promotion and increased potassium uptake of cotton and rape by a potassium releasing strain of
Bacillus edaphicus. Soil Biology and Biochemistry, 37, 1918-1922. DOI: 10.1016/j.soilbio.2005.02.026

Singh, I. (2018). Plant Growth Promoting Rhizobacteria (PGPR) and their various mechanisms for plant growth enhancement in stressful conditions: a review. European Journal of Biological Research, 8(4), 191-213. DOI: 10.5281/zenodo.1455995

Tariq, M., Hameed, S., Yasmeen, T., Zahid, M., \& Zafar, M. (2014). Molecular characterization and identification of plant growth promoting endophytic bacteria isolated from the root nodules of pea (Pisum sativum L). World Journal of Microbiology and Biotechnology, 30, 719-725. DOI: $10.1007 / \mathrm{s} 11274-013-$ $1488-9$

Teotia, P., Kumar, V., Kumar, M., Shrivastava, N., \& Ajit, V. (2016). Rhizosphere Microbes: Potassium Solubilization and Crop Productivity - Present and Future Aspects. In Potassium Solubilizing Microorganisms for Sustainable Agriculture (V.S. Meena, pp. 315-325). DOI: 10.1007/978-81-322-2776-2_22

Zhang, C., \& Kong, F. (2014). Isolation and identification of potassium-solubilizing bacteria from tobacco rhizospheric soil and their effect on tobacco plants. Applied Soil Ecology, 82, 18-25. DOI: 10.1016/j.apsoil.2014.05.002 